\title{
CEC (CENTER ECOLITERACY OF CIBEBER) PUSAT KEGIATAN REDUCE, REUSE, DAN RECYCLE DALAM UPAYA MEWUJUDKAN KAWASAN CISEUPAN KELURAHAN CIBEBER SEBAGAI KAWASAN BESTARI (BERSIH, SEHAT, TERTIB, DAN LESTARI)
}

\author{
Ansori1, Dinno Mulyono ${ }^{2}$, dan Galih Dani Septiyan Rahayu ${ }^{3}$ \\ 1,2, 3 IKIP Siliwangi \\ 1 ansoryalb@ikipsiliwangi.ac.id ${ }^{2}$ dinno@ikipsiliwangi.ac.id ${ }^{3}$ galih040990@ikipsiliwangi.ac.id
}

\begin{abstract}
ABSTRAK
Program pengabdian kepada masyarakat adalah salah satu bagian dari tridharma perguruan tinggi. Oleh karena itu, menjadi suatu kewajiban bagi setiap dosen dan sivitas akademika lainnya untuk terlibat dalam program pengabdian kepada masyarakat. Kegiatan pengabdian masyarakat ini dilaksanakan di kelurahan Cibeber Kecamatan Cimahi selatan kota Cimahi. Tujuan dari kegiatan pengabdian masyarakat ini adalah untuk mewujudkan kawasan Ciseupan yang berada di kelurahan Cibeber menjadi kawasan yang bersih, sehat, tertib, dan lestari melalui kegiatan reduce, reuse, dan recycle. Metode pelaksanaan pada kegiatan pengabdian ini dikelompokan menjadi empat tahap kegiatan yaitu tahap persiapan teridir dari kegiatan observasi, pelaksanaan terdiri dari kegiatan penyuluhan dan pendampingan, evaluasi terdiri dari kegiatan mengevaluasi kegiatan, dan penyelesaian terdiri dari kegiatan penyusunan laporan dan publikasi luaran kegiatan pengabdian kepada masyarakat. Hasil dari kegiatan pengabdian masyarakat ini yaitu masyarakat memahami reduce, reuse, dan recycle, masyarakat memiliki keterampilan terkait dengan reduce, reuse, dan recycle, serta terwujudnya kesadaran masyarakat dalam mewujudkan kawasan bersih, sehat, tertib, dan lestari melalui kegiatan reduce, reuse, dan reccyle.
\end{abstract}

Kata Kunci : reduce, reuse, recycle, penyuluhan, pendampingan

\begin{abstract}
The community service program is one part of the tri dharma of higher education. Therefore, it is an obligation for every lecturer and other academic community to be involved in community service programs. This community service activity was held in Cibeber, Cimahi. The purpose of this community service activity is to realize the Ciseupan region in the Cibeber to be a clean, healthy, orderly and sustainable area through activities such as reduce, reuse and recycle. The method of implementation in this service activity is grouped into four stages of activity, namely the final preparation stage of the observation activities, the implementation consists of counseling and mentoring activities, evaluation consists of activities evaluating activities, and completion consisting of activities in preparing reports and publications on community service activities. The result of this community service is that the community understands reduce, reuse, and recycle, the community has skills related to reduce, reuse, and recycle, and the realization of public awareness in realizing clean, healthy, orderly and sustainable areas through reduce, reuse and recycle.
\end{abstract}

Keywords: reduce, reuse, recycle, counseling, mentoring

\section{A. PENDAHULUAN}

Kelurahan Cibeber terletak di Kecamatan Cimahi Selatan Kota Cimahi Propinsi Jawa Barat. Kelurahan Cibeber memiliki luas wilayah 332,56 ha dengan jumlah penduduk 22.299. Potensi kelembagaan di Kelurahan Cibeber, yaitu PKK berjumlah 816 orang dan karang taruna berjumlah 45 orang, dan LPM berjumlah 12 anggota. Mata pencaharian pokok, yaitu pengrajin 345 orang dan wiraswasta 3.455. Hasil survey yang telah kami 
lakukan adalah Kelurahan Cibeber memiliki lahan resapan air yaitu di Kawasan Ciseupan yang kini beralih fungsi menjadi TPS (Tempat Pembuangan Sampah) liar yang akan berdampak buruk terhadap lingkungan. Hal ini terjadi karena kurangnya kepedulian masyarakat terhadap lingkungan sekitar dan kurangnya pemahaman masyarakat terhadap sampah yang dihasilkannya. Dengan adanya program CEC (Center Ecoliteracy of Cibeber) yang merupakan pusat kegiatan Reduce, Reuse, dan Recycle masyarakat dalam pengelolaan sampah di Ciseupan, maka akan terwujud kawasan Ciseupan BESTARI (Bersih, Sehat, Tertib, dan Lestari). Adapun peta lokasi dan permasalahannya sebagai berikut:

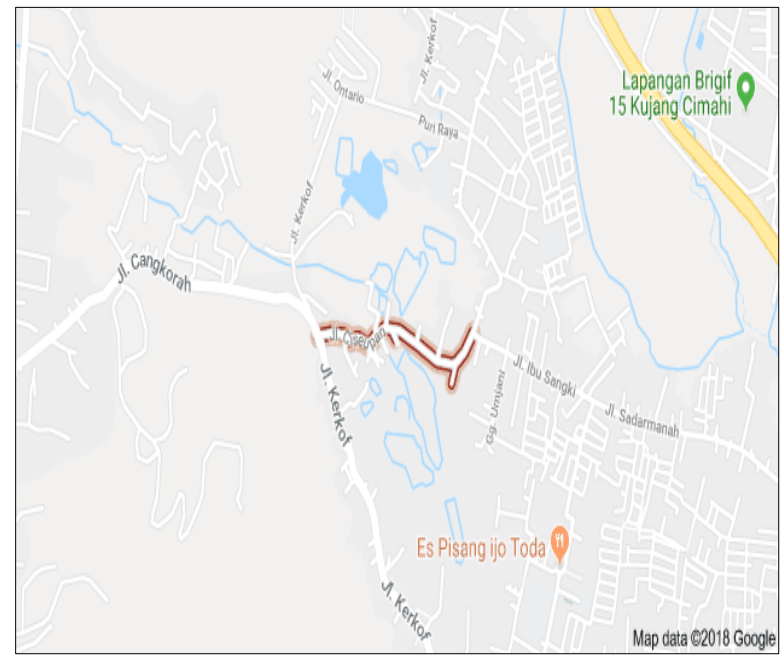

Gambar 1. Peta lokasi kawasan Ciseupan

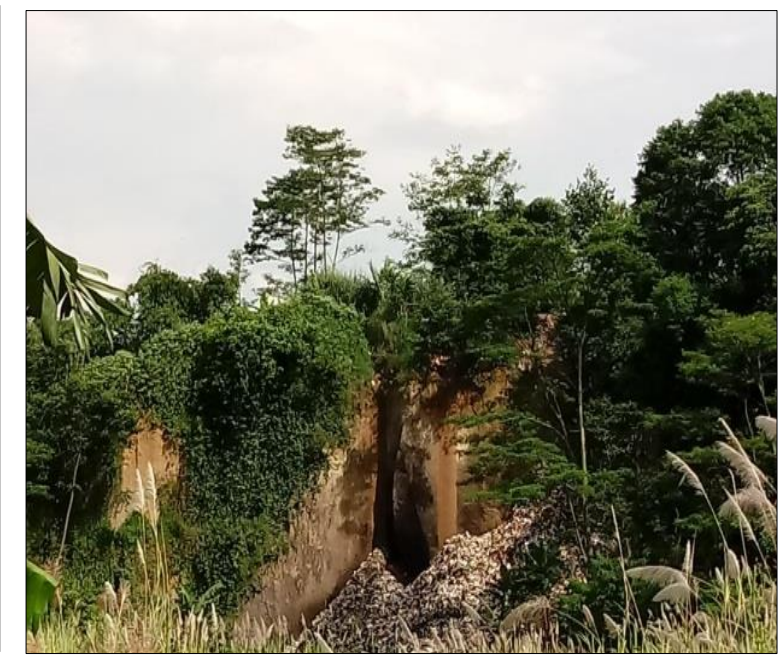

Gambar 2. Permasalahan Sampah Ciseupan

Kawasan Ciseupan di Kelurahan Cibeber yang merupakan lahan resapan air kini beralih fungsi menjadi TPS (Tempat Pembuangan Sampah) liar yang akan berdampak buruk terhadap lingkungan. Hal ini terjadi karena tidak ada bak sampah atau lahan untuk dijadikan TPS, belum adanya program yang khusus dalam mengelola sampah dari lembaga-lembaga desa mitra, tidak ada tempat sampah sebagai pemilahan jenis-jenis sampah, dan kurangnya pengetahuan masyarakat mengenai pengelolaan sampah. Masalah prioritas yang dipilih pada kegiatan pengabdian ini yaitu bidang pendidikan dalam arti meningkatkan pemahaman masyarakat Ciseupan terakit dengan pengelolaan dan pengolahan sampah berupa tiga jenis kegiatan yaitu reduce, reuse, dan recycle.

Tujuan dari pengabdian ini yaitu dengan adanya program CEC (Center Ecoliteracy of Cibeber) yang merupakan pusat kegiatan masyarakat dalam mengatasi sampah melalui metode reduce, reuse, dan recycle di Ciseupan, maka diharapkan akan terwujud kawasan Ciseupan sebagai kawasan BESTARI (Bersih, Sehat, Tertib, dan Lestari). Bersih disini 
berarti tidak akan ada lagi tumpukan sampah ditempat yang bukan seharusnya. Sehat berarti tidak aliran air besih tidak terganggu lagi oleh tumpukan sampah sehingga ketersedian air bersih semakin banyak, Tertib berarti warga sudah memahami cara membang sampah sesuai jenisnya dan membuangnya ke tempat smapah yang sudah disediakan, dan Lestari yaitu ketika warga disana memahami pengolahan sampah maka akan lebih mudah dalam melestarikan objek wisata disana dengan mengolah sampah menjadi barang-barang atau keterampilan yang mempunyai nilai jual lebih.

Dengan beragam permasalahan dalam pengelolaan sampah di Kelurahan Cibeber, membutuhkan adanya program yang dapat menumbuhkembangkan kesadaran dan pengetahuan masyarakat mengenai bentuk-bentuk penanganan sampah yang benar dan sesuai dengan standar pengelolaan lingkungan. Hal ini juga selaras dengan program pemerintah kota Cimahi yang mencanangkan program Zero Waste di wilayah Kota Cimahi. Dengan demikian, diperlukan penanganan yang menyeluruh dan melibatkan berbagai pengampu kepentingan dalam pengelolaan dan penanganan sampah mulai dari lingkungan keluarga. Program pengabdian ini dilakukan untuk melaksanakan proses penanganan sampah yang menyeluruh dan berkesinambungan.

\section{B. LANDASAN TEORI}

\section{Kawasan Ciseupan Kelurahan Cibeber Kecamatan Cimahi Selatan Kota Cimahi}

Kelurahan Cibeber terletak di Kecamatan Cimahi Selatan Kota Cimahi provinsi Jawa Barat. Kelurahan Cibeber memiliki beberapa potensi mulai dari potensi sumber daya alam hingga sumber daya manusia. Dari segi sumber daya alam Kelurahan Cibeber memiliki luas wilayah 665.12 ha dan objek wisata yang menarik. Kelurahan Cibeber memiliki lembaga kemasyarakatan, diantaranya 14 RW, 87 RT, masyarakat yang mengikuti organisasi PKK berjumlah 816 orang, karang taruna 45 orang, dan LPM berjumlah 12 anggota. Sehingga target jumlah tokoh masyarakat yang akan terlibat adalah 900 orang, diantaranya adalah masyarakat yang megikuti organisasi dan perwakilan dari setiap RT. Kelurahan Cibeber memiliki 22.299 penduduk dan total yang memiliki mata pencaharian pokok berjumlah 17.629 orang dan sisanya tidak memiliki mata pencaharian pokok.

Kelurahan Cibeber memiliki kegiatan yang berjumlah 40 kegiatan yang merupakan program kerja kelurahan. Kegiatan tersebut seperti Peringatan Hari Besar Negara (PHBN) dan Peringatan Hari Besar Islam (PHBI). Salah satu kegiatan yang termasuk ke 
dalam kegiatan yang berkaitan dengan lingkungan hidup adalah optimalisasi pengelolaan sampah dan pengembangan RW hijau. Adapun grafik sebaran masyrakat kelurahan Cibeber. Secara kuantitatif potret dan profil masyarakat sasaran sebagian besar masyarakat sasaran bekerja sebagai buruh dan wiraswasta, dan pendidikan masyarakat sebagian besar lulusan SMA/Sederajat. Adapun gambar dari sebaran masyarakat berdasar mata pencaharian dan jenjang pendidikan adalah sebgai berikut.
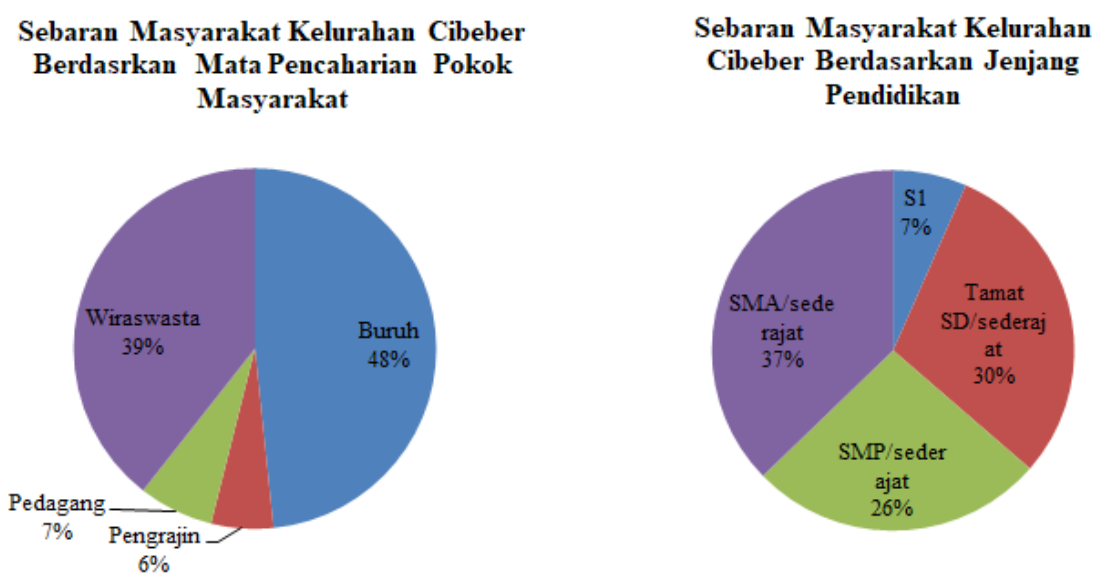

Gambar 3. Sebaran masyarakat kelurahan Cibeber berdasarkan mata pencaharian dan jenjang pendidikan

\section{Kecerdasan Ekologis sebagai Respon Kepedulian Krisis Ekologis}

Kecerdasan ekologis yaitu kemampuan kita untuk beradaptasi terhadap ceruk ekologis tempat kita berada. Ekologis artinya pemahaman tehadap organisme dan ekosistemnya, sedangkan kecerdasan adalah kapasitas untuk belajar dari pengalaman dan secara efektif berhadapan dengan lingkungan (Goleman, 2010). Kecerdasan ekologis sering pula disebut ecological literacy atau ecoliteracy. Menurut Capra (1995) ecological literacy terkait dengan prinsip-prinsip organisasi ecosystem untuk menunjang sustainable human society. Untuk mencapai hal itu diperlukan berpikir sistemik (systems thinking) yang mengakui bahwa dunia ini merupakan satuan yang terpadu (integrated) dan bukan sebagai kumpulan dari unsur-unsur yang terpisah. Dalam systems thinking itu adalah penting untuk memahami saling ketergantungan antara sistem ekologis dan sistem sosial atau sistem lainnya pada semua tingkatan.

Dari pengertian di atas dapat diambil kesimpulan bahwa kecerdasan ekologis itu adalah kemampuan kita dalam menerapkan apa yang telah kita pelajari dan pengetahuan kita terhadap akibat yang ditimbulkan terhadap lingkungan sekitar, sehingga dengan itu kita bisa memilih dalam menggunakan suatu produk yang kita 
anggap aman untuk kita tanpa menimbulkan efek samping dan kitapun akan terbiasa dalam melakukan hal-hal yang bersifat ramah lingkungan.

Menurut Goleman (2010) Kecerdasan ekologis memadukan keterampilan kognitif dengan empati terhadap segala bentuk kehidupan. Kecerdasan ekologis memungkinkan kita untuk memahami sistem dengan kompleksitasnya, juga saling mempengaruhi di antara alam dan dunia ciptaan manusia. Tetapi, pemahaman seperti itu membutuhkan pengetahuan yang sangat luas, sedemikian luasnya sehingga tak satu otak pun mampu menyimpan semuanya. Kita semua butuh bantuan orang lain untuk melayani kompleksitas kecerdasan ekologis.

Meningkatkan kecerdasan ekologis sangat dibutuhkan, karena dewasa ini sikap masyarakat sudah semena-mena terhadap lingkungan sekitar sehingga akan membawa bencana bagi lingkungan sekitar. Kekeringan, krisis air bersih, banjir, kebakaran, tanah longsor, semakin menipisnya lapisan ozon adalah beberapa bencana yang diakibatkan oleh perbuatan manusia yang egois dengan tidak memikirkan akibat dari tidak seimbangnya ekologi yang merugikan kita sendiri. Hal ini sejalan dengan yang dikemukan oleh Kahn (2010) yang menyebutkan bahwa dewasa ini banyak sekali manusia yang mengabaikan keseimbangan ekologis sehingga banyak sekali terjadi permasalahan lingkungan dan sebagai salah satu upaya dalam menghadapi hal tersebut yaitu melalui pendidikan yang menitik beratkan pada kecerdasan ekologis.

Menurut Supriatna (2013) kecerdasan ekologis atau ecoliteracy dapat terbentuk melalui pendidikan baik formal maupun informal. Dalam pandangan Stone dan Barlow (2005) untuk mencapai ecoliteracy diperlukan pendidikan lingkungan hidup (environment education, EE) baginya semua pendidikan adalah pendidikan lingkungan hidup yang tidak hanya menekankan pada aspek pengetahuan melainkan pembelajaran yang meaningful yang menyatukan antara kepala, tangan dan hati. Green behavior akan terbentuk setelah para siswa atau masyarakat pembelajar memperoleh pendidikan untuk membangun kesadaran tentang pentingnya menjadikan mereka sebagai bagian dari alam. EE juga diadopsi oleh semua mata pelajaran di sekolahsekolah di Indonesia termasuk IPS dengan tujuan untuk menangkal isu- isu lingkungan serta membekali para peserta didik pengetahuan, sikap dan keterampilan hidup ramah dengan lingkungan. 


\section{Reduce, Reuse, dan Recycle (3 R)}

Reduce dapat diartikan sebagai upaya dalam mengurangi penggunaan dan pembelian barang-barang yang tidak terlalu bermanfat dalam kehidupan sehari-hari. Hal ini dilakukan dalam upaya mengurangi sampah dalam kehidupan sehari-hari. Adapun contoh penerapannya adalah membawa air minum dari rumah, membawa bekal makanan dari rumah, membaca artikel, koran, dan majalah online serta membawa kantong belanja sendiri dari rumah ketika berbelanja.

Reuse adalah menggunakan kembali barang yang sudah tidak terpakai dalam kehidupan sehari-hari dalam upaya mengurangi sampah dalam kehidupan sehari-hari. Adapun contoh penerapan reuse adalah penggunaan botol bekas minum untuk tempat minyak atau tempat sabun cuci, menggunakan kertas bekas atau kertas print yang salah untuk mencatat, dan menggunakan baju bekas sebagai lap pel di rumah.

Recycle adalah mendaur ulang barang-barang yang sudah tidak terpakai menjadi barang-barang yang dapat dipakai lagi. Adapun contoh recycle dalam kehidupan seharihari seperti membuat tempat sampah dari botol bekas, membuat tempat pensil dari koran bekas, membuat hiasan dari kertas bekas dan sampah plastik.

\section{Bersih, Sehat, Tertib, dan Lestari (BESTARI)}

Bersih disini berarti tidak akan ada lagi tumpukan sampah ditempat yang bukan seharusnya. Sehat berarti tidak aliran air besih tidak terganggu lagi oleh tumpukan sampah sehingga ketersedian air bersih semakin banyak, Tertib berarti warga sudah memahami cara membang sampah sesuai jenisnya dan membuangnya ke tempat smapah yang sudah disediakan, dan Lestari yaitu ketika warga disana memahami pengolahan sampah maka akan lebih mudah dalam melestarikan objek wisata disana dengan mengolah sampah menjadi barang-barang atau keterampilan yang mempunyai nilai jual lebih.

\section{METODE PELAKSANAAN}

Berdasarkan hasil survei ke kelurahan Cibeber ditemukan potensi-potensi yaitu Kawasan Ciseupan sebagai kawasan resapan air, terdapat objek wisata Pancakaki Refresh Area, organisasi PKK berjumlah 816 orang, karang taruna berjumlah 45 orang, mata pencaharian pokok pengrajin berjumlah 345 orang. Sedangkan permasalahan yang ditemukan yaitu alih fungsi kawasan Ciseupan sebagai kawasan resapan air yang kini beralih fungsi menjadi TPS liar. Sasaran program PKMS ini seluruh masyarakat 
kelurahan Cibeber yang memiliki potensi-potensi seperti yang di kemukakan di atas. Luaran yang diharapkan dari program PKMS ini yaitu timbulnya pemahaman, rasa sadar, dan keterampilan pada masyarakat tentang pengolahan sampah melalui kegiatan reduce, reuse, dan recycle.

Kelurahan Cibeber Bestari (bersih, sehat, tertib dan lestari). Adapun metode yang digunakan untuk mewujudkan luaran-luaran yang dikemukakan tersebut yaitu dilakukan melalui pemberdayaan masyarakat dengan pendampingan atau workshop secara berkala dan menjalin kemitraan dengan berbagai pihak yang dapat mewujudkan keberlanjutan program CEC di Kelurahan Cibeber. Adapaun metode pelaksanaan kegiatan secara lengkap adalah sebagai berikut.

\section{Survei awal}

Survei awal dilaksanakan melalui pedoman observasi dan studi dokumentasi untuk melihat gambaran masyarakat dan permasalahan di masyarakat sebelum masyarakat tersebut dijadikan sebagai masyarakat sasaran pada program PKMS ini.

2. Identifikasi masalah

Identifikasi masalah yang dilakukan dalam rangka kegiatan PKMS ini secara umum berdasarkan hasil survei, potret, dan profil masyarakat sasaran yang telah digambarkan pada sub-bab sebelumnya, dimana masyarakat sasaran dilihat dari sebaran mata pencaharian sebagian besar bekerja sebagai buruh, wiraswasta, pedagang, pengrajin, dan tidak bekerja. Dilihat dari sebaran jenjang pendidikan masyarakat sasaran sebgian besar lulusan SMA/Sederajat, SMP/Sederajat, SD/Sederajat, dan S1/Sederajat. Hal ini membuktikan masyarakat di Kelurahan Cibeber memiliki potensi untuk mewujudkan kelurahan Cibeber BESTARI dan meningkatkan ekonomi masyarakat melalui kegiatan pada program CEC (pengolahan sampah organik menjadi pupuk kompos dan pengolahan sampah anorganik menjadi barang-barang keterampilan yang mempunyai nilai jual.

\section{Analisis kebutuhan}

Analisis kebutuhan berdasarkan survei melalui observasi, studi dokumentasi, dan wawancara kepada masyarakat yaitu kurangnya pemahaman, kesadaran, dan keterampilan masyarakat dalam pengolahan sampah dan pelestarian lingkungan sehingga terjadi alih fungsi kawasan resapan air menjadi tempat pembuangan sampah liar. 
4. Penetapan khalayak sasaran

Penetapan masyarakat dilakukan berdasarkan hasil survei dan analisis kebutuhan masyarakat, sehingga ditetapkan kelurahan Cibeber Kecamatan Cimahi Selatan Kota Cimahi sebagai masyarakat sasaran pada program PKMS ini.

5. Penyusunan program

Penyusunan program kegiatan PKMS ini dilakukan dalam rapat rutin yang diselenggarakan setiap minggunya yang dihadiri oleh para stakeholder program PKMS.

6. Perumusan dan pengukuran indikator keberhasilan

Penyusunan dan pengukuran indikator keberhasilan program kegiatan PKMS ini dilakukan dalam rapat rutin yang diselenggarakan setiap minggunya yang dihadiri oleh para ketua dan anggota program PKMS.

7. Pelaksanaan Program

Pelaksanaan program mengacu pada jadwal kegiatan dan indikator keberhasilan program yang telah disusun.

8. Strategi pembinaan khalayak sasaran

Strategi yang digunakan dalam mewujudakan luaran-luaran yang dikemukakan di poin sebelumnya yaitu melalui sosialisasi, kerjasama dengan lembaga-lembaga pemerintah kelurahan, tokoh masyarakat, lembaga-lembaga dalam bidang lingkungan hidup, dilakukan pendampingan/workshop secara berkala kepada masyarakat sasaran.

9. Monitoring dan evaluasi berdasarkan indikator keberhasilan program

Monitoring dan evaluasi dilakukan berdasarkan indikator keberhasilan program yang telah disusun.

10. Penyusunan laporan

Penyusunan laporan hasil kegiatan PKMS mengikuti rancangan jadwal yang diagendakan oleh tim sesuai panduan PKMS.

\section{HASIL DAN PEMBAHASAN}

\section{Hasil}

Kegiatan pengabdian masyarakat ini dilaksanakan di kelurahan Cibeber Kecamatan Cimahi selatan Kota Cimahi dengan subjeknya adalah masyarakat kelurahan Cibeber yang berada dikawasan Ciseupan. Kegiatan pengabdian ini bertujuan untuk meningkatan pemahaman, keterampilan, dan kesadaran dalam prilaku hidup bersih dan 
sehat khusunya dalam pengelolaan dan pengolahan sampah dengan wujud $3 \mathrm{R}$ yaitu reduce, reuse, dan recycle.

Kegiatan pengabdian berupa penyuluhan dan pendampingan secara berkala kepada masyarakat terkait kegiatan 3R tersebut dilaksankan selama empat bulan yaitu dari bulan April - Juli 2019 denga melibatkan tim pengabdian dan bekerjasama dengan para mitra yang ada di kelurahan Cibeber seperti aparat pemerintahan kelurahan Cibeber dan lembaga-lembaga di kelurahan tersebut seperti PKK dan karang taruna.

Keberhasilan kegiatan pengabdian kepada masyarakat ini diukur sesuai dengan indikator-indikator yang telah disusun oleh tim pengabdian masyarakat. Adapun hasil dari pengabdian kepada masyarakat ini adalah sebagai berikut :

Tabel 1. Hasil Pengabdian Kepada Masyarakat di Kelurahan Cibeber Kec. Cimahi Selatan Kota Cimahi

\begin{tabular}{|c|c|c|c|}
\hline INDIKATOR & SEBELUM & $\begin{array}{c}\text { KEGIATAN } \\
\text { PENGABDIAN }\end{array}$ & SETELAH \\
\hline $\begin{array}{l}\text { Perubahan } \\
\text { prilaku } \\
\text { masyarakat }\end{array}$ & $\begin{array}{l}\text { Kurangnya } \\
\text { pemahaman } \\
\text { masyarakat } \\
\text { tentang } \\
\text { pemilahan dan } \\
\text { pengolahan } \\
\text { sampah. Serta } \\
\text { kurangnya } \\
\text { kepedulian } \\
\text { masyarakat } \\
\text { terhadap } \\
\text { lingkungan. }\end{array}$ & $\begin{array}{l}\text { Penyuluhan dan } \\
\text { pendampingan } \\
\text { kegiatan } \\
\text { reduce, reuse, } \\
\text { dan recyle } \\
\text { kepada } \\
\text { masyarakat. }\end{array}$ & $\begin{array}{l}\text { Pengetahuan: } \\
\text { (Instrumen: Wawancara) } \\
\text { Hasil: Memahami reduce, reuse, dan recyle } \\
\text { dalam mewujudkan kawasan BESTARI. } \\
\text { Sikap: } \\
\text { (Instrumen Observasi/Dokumentasi) } \\
\text { Hasil: Terwujudnya kesadaran } \\
\text { masyarakat dalam mewujudkan kawasan } \\
\text { BESTARI melalui kegiatan reduce, reuse, } \\
\text { dan recyle. } \\
\text { Keterampilan: } \\
\text { (Instrumen Observasi/Dokumentasi) } \\
\text { Hasil: Memiliki keterampilan reduce, } \\
\text { reuse, dan recyle dalam mewujudkan } \\
\text { kawasan BESTARI. }\end{array}$ \\
\hline
\end{tabular}

Dilihat dari hasil pengabdian masyarakat pada tabel 1 dapat diartikan bahwa kegiatan pengabdian kepada masyarakat tersebut memberikan dampak yang positif dalam meningkatkan pemahaman, keterampilan, dan kesadaran dalam pengelolaan dan pengolahan sampah untuk mewujudkan kawasan BESTARI. Adapun keberhasilan 
kegiatan pengabdian kepada masyarakat ini dapat dilihat pada gambar di bawah ini.
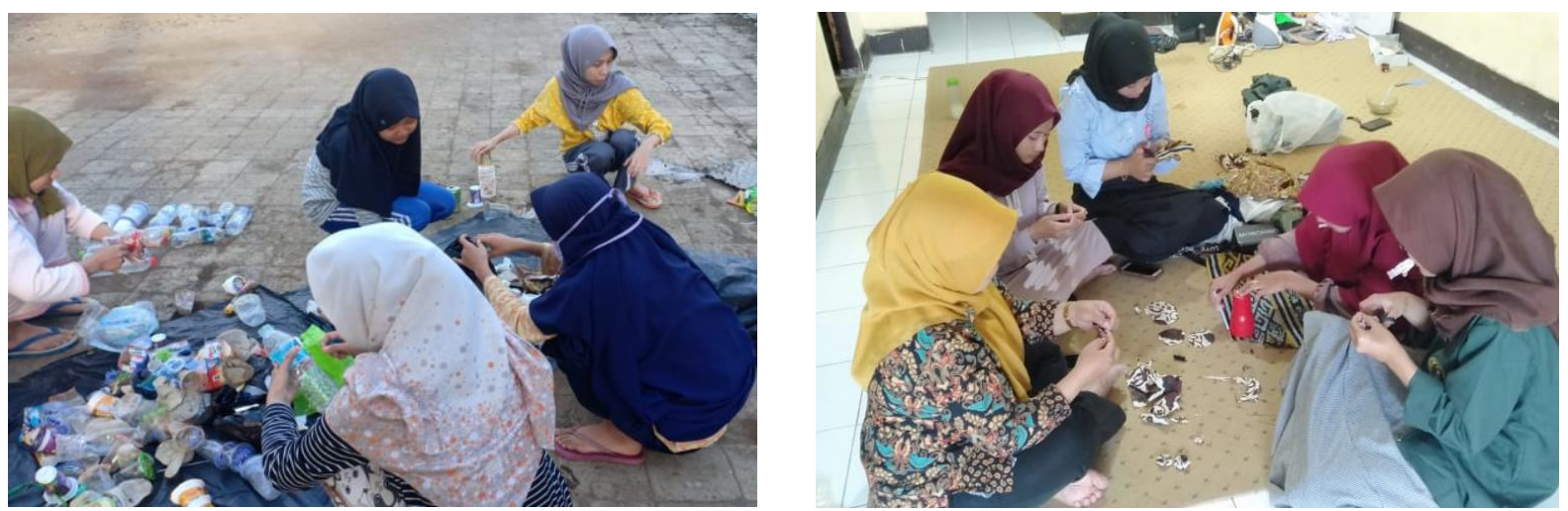

Gambar 4. Kegiatan Pengolahan sampah

\section{Pembahasan}

Selama proses kegiatan pengabdian kepada masyarakat di kelurahan Cibeber kecamatan Cimahi selatan Kota Cimahi diperoleh temuan-temuan menarik. Temuan menarik ketika pelaksanaan pengabdian masyarakt berlangsung yaitu kegiatan penyuluhan dan pendampingan lebih mudah dilaksanakan apabila dikaitkan dengan kearifan lokal dan kebiasaan masyarakat setempat hal ini sejalan dengan yang dikemukakan oleh Bahtiar (2016) dan Saputra (2013) bahwa pembelajaran, pendampingan, dan kegiatan lainnya apabila dilaksankan dengan memanfaatkan kearifan lokal dan kebiasaan masyarakat yang ada maka akan memberikan kemudahan dalam pelaksanaan kegiatan dan memberikan dampak yang positif dalam berbagai hal. Kearifan lokal disana misalnya dalam bentuk pertemuan-pertemuan rutin yang mencerminkan sifat gotong royong di tengah masyarakat yang masih kental. Walaupun komposisi penduduk secara umum telah berubah dan cenderung heterogen dibandingkan dengan komposisi penduduk di pedesaan. Hal ini karena kota Cimahi, memberikan kesempatan kepada warga pendatang untuk bersama-sama terlibat dalam pembangunan. Namun, dengan sifat heterogen tersebut justru memberikan nuansa yang lebih luas dan kental dengan berbagai sistem pendekatan yang semakin beragam dan saling melengkapi satu sama lain. Bentuk-bentuk kearifan lokal, terutama dalam budaya Sunda masih menjadi salah satu penguatan utama dalam pengembangan sistem kerjasama dan sistem sosial yang ada di Kelurahan Cibeber.

Temuan lainnya ketika proses kegiatan pengabdian masyarakat yaitu kegiatan pengabdian membutuhkan perencanaan yang matang dan pendekatan kepdaa subjek pengabdian yaitu masyarakat sehingga masyarakat tidak merasa kaget ketika tim pengabdian memberikan penyuluhan dan pendampingan kepada masyarakat. Hal ini sejalan dengan yang dikemukakan oleh Rahayu dan Firmansyah (2018) bahwa kegiatan pengabdian kepda 
masyarakat akan lebih mudah dilaksanakan ketika direncanakan dengan matang dan pendekatan yang tepat kepada masyarakat. Dengan perencanaan yang matang, pendekatan dikaitkan dengan program pendampingan keluarga yang menjadi sasaran utama dalam program pengabdian ini. Hal ini karena, keluarga adalah satuan sosial terkecil di tengah masyarakat dan akan menjadi salah satu satuan pendidikan informal yang memberikan pengalaman berharga bagi seluruh anggota masyarakat yang ada di dalamnya sepanjang keluarga tersebut dapat memberikan peran yang utuh bagi setiap anggotanya (A.S. Akhyadi \& Mulyono, 2018).

Temuan selanjutnya dalam proses pengabdian kali ini adalah adanya partisipasi masyarakat yang relatif tinggi. Hal ini diindikasikan dengan tingginya kehadiran dan keterlibatan masyarakat dalam berbagai kegiatan seperti pelatihan dan seminar yang dilaksanakan di Kelurahan Cibeber, Kota Cimahi. Ternyata hal ini relevan dengan pendapat dari Saepudin dan Mulyono (2019) yang mengemukakan tentang proses pemberdayaan perlu dikaitkan dengan pendekatan ekonomi. Program pengabdian yang dilaksanakan tidak hanya memberikan pengetahuan, tapi juga memberikan stimulus berupa pengolahan sampah menjadi barang yang memiliki nilai ekonomis. Pada beberapa pelatihan, masyarakat diberikan pelatihan untuk proses pembuatan beragam kerajinan tangan, de coupage dan produk kreatif lainnya yang bisa dijual, sehingga memberikan manfaat secara ekonomi. Dengan demikian, proses pengabdian tidak hanya berupa hilirisasi program penelitian semata, tapi berimplikasi terhadap peningkatan kualitas kehidupan masyarakat secara ekonomi, dan ini yang mendorong adanya partisipasi aktif dari masyarakat.

\section{E. KESIMPULAN}

Berdasarkan hasil pelaksanaan pengabdian pada masyarakat yang telah dilaksankan di kelurahan Cibeber Kecamatan Cimahi Selatan Kota Cimahi, maka dapat disimpulkan hal-hal sebagai berikut:

1. Kegiatan pengabdian pada masyarakat ini dapat memberikan manfaat langsung kepada mayarakat Cibeber khususnya masyarakat di kawasan Ciseupan dalam meningkatkan pemehaman, keterampilan, dan kesadaran pengolahan dan pemilahan sampah.

2. Kegiatan pengabdian pada masyarakat ini dapat dijadikan sarana berinovasi dalam usaha mewujudkan lingkungan bersih, sehat, tertib dan lestari khusunya dari sampah. 
3. Wahana atau laboratorium bagi para dosen dalam mengimplementasikan teori, pengetahuan, dan keterampilan secara nyata, dan bermanfaat bagi masyarakat luas.

\section{F. UCAPAN TERIMA KASIH}

Terima kasih kepada Direktorat Riset dan Pengabdian Masyarakat, Direktorat Jenderal Penguatan Riset dan Pengembangan Kementerian Riset, Teknologi, dan Pendidikan Tinggi yang telah memberikan kesempatan melalui program pengabdian Kemitraan Masyarakat Stimulus (PKMS) sehingga kegiatan pengabdian ini dapat berjalan dengan lancer dan sesuai harapan.

\section{G. DAFTAR PUSTAKA}

Akhyadi, A. S., \& Mulyono, D. (2018). Program parenting dalam meningkatkan kualitas pendidikan keluarga.Abdimas Siliwangi: Jurnal Pengabdian Kepada Masyarakat, 1(1), 1-8.

Bahtiar, M. A. (2016). Kurikulum development of environmental education based on local wisdom at elementary school. Jurnal Internasional of Learning Teaching and Educational Research. Universitas Muhammadiyah. Gresik.

Capra, F. (1995). The web of life. Harper Collins. [Online] Diakses dari http://www.ecoliteracy.org/publications/frijop. [27 Maret 2016]

Goleman, D. (2010). Ecological intelligence/ kecerdasan ekologi. Jakarta: PT. Gramedia Pustaka Utama.

Kahn, R. (2010). Critical pedagogy, ecoliteracy, \& planetary crisis, the ecopedagogy movement. New York: Peter Lang Publishing.

Rahayu, G.D.S dan Firmansyah, D. (2018). Pengembangan pembelajaran inovatif berbasis pendampingan bagi guru sekolah dasar. Jurnal Abdimas Siliwangi, 1 (1), 17-25.

Saepudin, A., \& Mulyono, D. (2019). Community education in community development. EMPOWERMENT: Jurnal Ilmiah Program Studi Pendidikan Luar Sekolah, 8(1), 65-73.

Saputra. (2013). Enhacing local wisdom through local content of elementary school in java. Jurnal of Global Summit on Education. Universitas Indonesia. Depok.

Stone M.K. dan Barlow. (2005). Ecological literacy: educating our children for a sustaianable world. San Francisco: Siera Club Book. 
Supriatna, N. (2013). Developing green behavior through ecopedagogy in social studies learning in elementary schools in bandung, indonesia. Department Of Social Studies, Indonesia University Of Education. Bandung. 